\title{
Effect of Four Different Formulated Rations on Production Performance and Egg Quality Traits of Fayoumi Chickens
}

\author{
Tesfa Geleta \\ Oromiya Agricultural Research Institute, Adami Tulu Agricultural Research Center, Zeway, Ethiopia \\ Email address: \\ ngtesfa@gmail.com

\section{To cite this article:} \\ Tesfa Geleta. Effect of Four Different Formulated Rations on Production Performance and Egg Quality Traits of Fayoumi Chickens. \\ International Journal of Biomedical Materials Research. Vol. 8, No. 2, 2020, pp. 20-24. doi: 10.11648/j.ijbmr.20200802.12
}

Received: October 8, 2020; Accepted: November 26, 2020; Published: December 11, 2020

\begin{abstract}
Four experimental rations were formulated from locally available protein and energy source feed to study its effect on the production performance, on some egg quality traits for fayoumi chickens and to know the financially feasibility of such locally formulated rations for fayoumi layer chickens. Ninety six fayoumi chickens of 24 weeks of age were subjected to four formulated rations. Each of the four treatments were replicated three times with 8 birds ( 1 male: 7 females) per replicate. Each replicate feed was fed in group in feeding pens. Feed intake and egg production data were collected daily for each replicate. Dry matter feed intake was not significantly different $(\mathrm{P}>0.05)$ between treatments 1 and 3 , and between treatments 2 and 4. Significantly higher $(\mathrm{P}<0.05)$ egg production and egg weight were observed in treatment 2 with no significant difference $(\mathrm{P}>0.05)$ among the other three treatments. Egg shell weight $(\mathrm{g})$, shell thickness $(\mathrm{mm})$ and Yolk color did not differ $(\mathrm{P}>0.05)$ significantly among the treatments. In the current study net profit of 47.2, 39.4, 21.41 and 15.3 Ethiopian Birr were obtained per bird on treatments 2, 3, 4 and 1 respectively within six months of feeding period. Locally available protein and energy source feed can be used for the formulation of nutritionally balanced and economically feasible diet for fayoumi layers chickens. Ration formulated from $0.5 \%$ limestone, $0.5 \%$ salt, $1 \%$ layers premixes, $28 \%$ wheat bran, $3.5 \%$ fish meal, $11.5 \%$ soybean, $32 \%$ maize and $23 \%$ noug cake was found to be financially feasible and recommendable in areas with similar climatic conditions to Adami Tulu area and in area where these feed ingredients are available.
\end{abstract}

Keywords: Formulated Rations, Financially Feasible, Layers Ration, Net Return, Ingredients

\section{Introduction}

Fayoumi chickens are one of the egg producing breeds introduced to Ethiopia. It is originated from Egypt, hardy and very precious in being early maturing [1]. They mature at very young age of 4-5 months, lay good number of white cream eggs, have excellent resistance to viral and bacterial diseases, can cope with hot conditions and are excellent foragers [2]. Considering their production traits, the breed was brought to mid rift valley of Ethiopia to distribute for farmers. However in mid rift valley of Ethiopia both introduced pure exotic chickens breed and commercial breeds did not express their production potential after distribution mainly due to lack quality supplementary feed. In mid rift valley of Ethiopia there is a shortage of commercial poultry feed suppliers and poultry production characterized with inadequate feeding system [3]. The price of commercial feed also raised up and not economical for small holder poultry producer to use it. On the other hand; a newly introduced breed cannot expressed their full production potential and even cannot survive unless the problem of feeding solved. Locally available feed sources have a potential to fill the gap when it mixed with care to formulate economically and nutritionally balanced diet. Identifying some of the protein source and energy source feed and formulating diets with balanced nutrient is the recommended policy for chickens feeding $[4,5]$.

Many protein and energy source feeds are available in mid rift valley area that can be used as feed ingredients to formulate supplementary poultry feed. Soybean is one of the best protein sources feed for chickens and cultivated in mid rift valley of Ethiopia. It contains 40 to 48 percent crude protein depending on the amount of hulls removed and the oil extraction procedures [6]. It is also possible to use fishmeal in mid rift valley area as layers ration as it is highly available in the area. Nutritionally it has been widely used as a 
supplemental protein source for many years primarily for mono-gastric animals. Fish meal is the most important animal protein supplement used in poultry ration that contributed protein especially essential amino acid (aa) vitamin (B12) and minerals [7, 8]. It produced from clean dried ground tissue of un-decomposed fish residues remaining after processing for human food or industrial purposes. Noug seed cake is one of the oil seed cake commonly used as a protein supplement in the diet of animal and contained $28 \%$ to $38 \%$ protein [9] and highly available on local market.

As energy source maize produced in mid rift valley of Ethiopia and it is rich in carbohydrate and fat, contains $8 \%$ $\mathrm{CP}$ and $14.5 \mathrm{KJ} / \mathrm{g}$ (kilojoules per gram) metabolizable energy [10]. Wheat bran is the outer fibrous layers separated from wheat grain with $12 \mathrm{MJ} / \mathrm{kg}$ metabolizable energy, quite palatable by-product and highly available on local market of mid rift valley of Ethiopia [9].

Using these locally available protein and energy source feed; it is possible to formulate economically affordable and nutritionally balanced diet for the introduced fayoumi chickens. Therefore, the study was done to formulate nutritionally and financially feasible ration from locally available feed source for the introduced fayoumi chickens.

\section{Material and Methods}

The experiment was conducted at Adami Tulu Agricultural Research Center. Adami Tulua Agricultural research center is located in the mid rift valley of Ethiopia at latitude of $7^{\circ} 9^{\prime} \mathrm{N}$ and $38^{\circ} 7^{\prime} \mathrm{E}$. The altitude of the area is 1650 meter above sea level. The average annual rain fall of the area was $949 \mathrm{~mm}$ with an average minimum and maximum temperatures of $14^{\circ} \mathrm{C}$ and $29.6^{\circ} \mathrm{C}$, respectively and the relative humidity of the area was 57.42 [11].

\subsection{Feed Management}

Fish meal was processed to separate the solids (fat-free dry matter), oil and water. It was made by cooking in barrel, then pressing and drying on sun and finally by grinding the dried fish meal. The processed fish meal was brought to Adami tulu agricultural research center from Batu aquatic and fishery resource research center and further dried and ground to be used as poultry feed. Soybean cultivated in Adami Tullu farm and toasted before grinding and added into the rations. Wheat bran, maize, noug cake, Limestone, layers premix, and salt were purchased from local market and added in to the rations. Four poultry rations were formulated using these both protein and energy source feed.

From each of the formulated diet 120 gram feed was daily provided for each chicken. Left over feeds of the treatment diets were collected every next day in the morning before providing feed for the day. Water was provided ad libitum. Eight chickens ( 7 females and 1 male) were randomly allotted to four dietary treatments each of which were replicated three times.
Table 1. Rations formulated from protein and energy source feed for fayoumi layers chickens.

\begin{tabular}{lllll}
\hline Feed ingredients & TR1 & TR2 & TR3 & TR4 \\
\hline limestone & 0.5 & 0.5 & 0.5 & 0.5 \\
salt & 0.5 & 0.5 & 0.5 & 0.5 \\
premixes & 1 & 1 & 1 & 1 \\
Wheat bran & 46 & 28 & 41 & 40 \\
Fish meal & 0 & 3.5 & 7.5 & 11.25 \\
soybean & 15 & 11.5 & 7.5 & 3.75 \\
maize & 24 & 32 & 28 & 26 \\
Noug cake & 13 & 23 & 14 & 17 \\
Total & 100 & 100 & 100 & 100 \\
\hline
\end{tabular}

$\mathrm{TR}=$ treatment

\subsection{Animal Management}

A total of 96 Fayoumi chickens of 24 weeks of age were selected from chickens reared in Adami Tulu research center. Litter housing system that was partitioned in to 12 equal sized pens $\left(4 \mathrm{~m}^{2}\right)$ was used. Before placing the experimental chickens in to the experimental pens the whole units were cleaned and disinfected with Dizinon disinfectant and littered with properly dried tef (Ergrostic tef) straw. The experimental house was electrically heated during night.

\subsection{Data Collected and Performance Parameters Considered}

Feeds offered to the chickens and refusals were measured every morning. The differences between offered and refusals were calculated as intake. Egg production were collected and recorded daily. Data on egg quality parameters were taken at the end of the experiment. Eggs were weighed using an electronic digital balance. Egg shell thickness was measured using electronic digital caliper and yolk color was determined by adjusting the score of yolk color on color fan from Roche.

\subsection{Statistical Analysis}

Analysis of variance of feed intake, egg production and egg quality parameters were done according to the general linear model (GLM) procedure of the Statistical Analysis System [12] software. Mean comparisons were made using Duncan Multiple Range Test procedure of the SAS package.

\subsection{Economic Analysis}

Variable costs collected from the prices of dry matter feed intake per bird, vaccine, medicine and disinfectant used. Net return was obtained from egg produced and sold during six months experimental period. The economic benefit was estimated by considering partial budget analysis, according to the formula developed by CIMMT [13, 14].

$$
\mathrm{NI}=\mathrm{TR}-\mathrm{TVC}
$$

Where, $\mathrm{NI}=$ Net income, $\mathrm{TR}=$ Total return, $\mathrm{TVC}=$ Total variable cost. 


\section{Results}

\subsection{Chemical Composition of the Rations}

The chemical compositions of the experimental rations used were analyzed at Adami Tulu animal nutrition laboratory and at National veterinary Institute. The dry matter
(DM\%), mineral matter (MM\%), crude fiber $(\mathrm{CF} \%)$, crude fat $(\%)$, calcium $(\mathrm{Ca} \%)$, Phosphorus $(\mathrm{P} \%)$ and crude protein $(\mathrm{CP} \%)$ composition of the formulated treatment rations were analyzed using the method of AOAC [15] proximate principle and given in (Table 2).

Table 2. Nutritional composition of experimental diet used for layer fayoumi chickens.

\begin{tabular}{llllllll}
\hline \multicolumn{2}{l}{ Nutrient (\%) } & & & & & \\
\hline TR & DM & MM & CF & Fat & Ca & P & CP \\
\hline 1 & 89.6 & 7.2 & 4.6 & 4.4 & 0.84 & 0.84 & 16.36 \\
2 & 86.4 & 8.6 & 5.1 & 3.2 & 0.92 & 0.96 & 16.50 \\
3 & 90.8 & 8.2 & 5.8 & 4.2 & 0.98 & 0.88 & 16.78 \\
4 & 86.9 & 8.0 & 5.4 & 2.8 & 0.85 & 0.82 & 2870 \\
\hline
\end{tabular}

$\mathrm{TR}=$ treatment, $\mathrm{DM} \%=$ dry matter percentage, $\mathrm{MM} \%=$ mineral mater percentage, $\mathrm{CF} \%=$ crude fiber percentage, $\mathrm{Ca} \%=$ calcium percentage, $\mathrm{P} \%=$ phosphorus percentage, $\mathrm{ME}=$ metabolizable energy, Kcal= kilocalorie

Feed intake, egg production performance and egg quality parameters of fayoumi chickens fed the rations formulated from protein and energy source local feed are given in table 3 below.

Table 3. Feed intake, egg production and egg quality parameters of fayoumi chickens (Mean $\pm S D)$.

\begin{tabular}{lllllll}
\hline TR & Feed intake/day (g) & Egg production Within six months & Egg weight (g) & Shell weight (g) & Shell thickness (mm) & Yolk color \\
\hline 1 & $86.4 \pm 8.2 \mathrm{~b}$ & $52 \pm 4.6^{\mathrm{b}}$ & $39.8 \pm 2.3^{\mathrm{b}}$ & $4.4 \pm 0.54$ & $0.32 \pm 0.03$ \\
2 & $94.6 \pm 10.4 \mathrm{a}$ & $64 \pm 5.6^{\mathrm{a}}$ & $42.6 \pm 3.1^{\mathrm{a}}$ & $4.6 \pm 0.51$ & $0.34 \pm 0.04$ \\
3 & $82.2 \pm 6.5 \mathrm{~b}$ & $56 \pm 4.8^{\mathrm{b}}$ & $39.2 \pm 2.4^{\mathrm{b}}$ & $4.3 \pm 0.53$ & $0.36 \pm 0.05$ \\
4 & $93.4 \pm 4.2 \mathrm{a}$ & $54.4 \pm 2.8^{\mathrm{b}}$ & $38.4 \pm 4.2^{\mathrm{b}}$ & $4.2 \pm 0.50$ & $0.37 \pm 0.02$ & $2.5 \pm 0.78$ \\
\hline
\end{tabular}

$\mathrm{SD}=$ standard deviation, $\mathrm{TR}=$ treatment, $\mathrm{g}=$ gram, $\mathrm{mm}=$ millimeter. superscripts in the same column with different letters are significantly different $(\mathrm{P}<0.05)$.

\subsection{Production Cost and Return of Fayoumi Chickens Reared Using Formulated Feed}

Variable costs were collected from the prices of dry matter feed intake per bird, from vaccine, medicine and disinfectant used per bird based up on price of data set collected for respective treatments. Money obtained from sale of total egg laid during experimental period was the source of income.
Fixed costs (feeders and waters) were taken from the previously purchased and used for flock and returned as soon as the trial finished and feeding pens were constructed previously by the farm and its cost were not included in calculation. The financial analysis of the experiment was computed and described for each treatment in the table 4 given below.

Table 4. Partial budget analysis for Fayoumi chickens.

\begin{tabular}{|c|c|c|c|c|}
\hline \multirow{2}{*}{ Partial budget cost } & \multicolumn{4}{|c|}{ Treatments (TR) } \\
\hline & 1 & 2 & 3 & 4 \\
\hline Total feed consumed in six months, $\mathrm{kg} / \mathrm{bird}$ & 15.48 & 17.03 & 15.00 & 16.81 \\
\hline Feed cost / kg (ETB) & 7.54 & 7.80 & 7.24 & 7.15 \\
\hline Total feed cost (ETB) & 116.7 & 132.80 & 108.6 & 120.19 \\
\hline Cost of Vaccine, Medicine and Disinfectant (ETB) & 21.00 & 21.00 & 21.00 & 21.00 \\
\hline Cost of feeding pen construction (Mish wire, poles and Bedding Material/teff straw/) (ETB) & 42.00 & 42.00 & 42.00 & 42.00 \\
\hline Total variable cost (TVC) (ETB) & 192.70 & 208.80 & 184.60 & 196.19 \\
\hline Price of total eggs laid (GR)(ETB) & 208.00 & 256.00 & 224.00 & 217.60 \\
\hline NR (GR-TVC) & 15.30 & 47.20 & 39.40 & 21.41 \\
\hline
\end{tabular}

$\mathrm{TR}=$ treatment, $\mathrm{ETB}=$ Ethiopian Birr, $\mathrm{TVC}=$ Total variable cost, $\mathrm{NR}=$ Net return, $\mathrm{GR}=$ Gross return

\section{Discussions}

There is no significant difference in feed intake between treatment one and treatment three, and between treatment two and treatment four most probably due to the similar fat and dry mater content of the corresponding treatment diets.
Significantly $(\mathrm{P}<0.05)$ higher dry mater feed intake was observed in treatments two and treatment four compared to treatment one and three. This could be due to the lower fat content of treatment two and four diets compared to the rest diets that agree with Valkonen et al. [16]. Dry mater feed intake in the current study is generally lower than the study done by Tesfa et al., khan et al. due to higher energy content 
of the current feed used. Higher energy content of the current feed caused lower feed intake that agree with Valkonen et al $[17,18]$. [16] report but disagree with the Riberio PAP et al. [19] who reported higher feed intake from using higher energy feed compared to using lower energy feed.

Significantly higher $(\mathrm{P}<0.05)$ egg production and egg weight were observed in treatment two compared to the rest treatments due to the higher dry matter feed intake and this agree with the report of Valkonen et al. [16] and Asghedom et al. [20].

Egg production performance of Fayoumi chickens in the current study is higher than the study done on the same breed by Tesfa et al. [21] but lower than the study done using commercial layer diet [17]. Egg production performances of Fayoumi chickens in the current study are lower than their egg production performance in middle Egypt as reported by Ann [2] and by khan et al. [18]. This is due to the lower dry matter feed intake compared to the findings of others.

Egg weight in the current experiment was also similar with the egg weight reported by Tesfa et al. [21] but lower than the egg weight observed from using commercial layer diet [17] and than the report of Khan et al. [18]. This is most probably due to the quality of protein in the diet and due to different dry matter intake.

Shell weight and shell thickness did not differ $(\mathrm{P}>0.05)$ significantly among treatments. This could be due to similar calcium and phosphors contents of the formulated rations as egg shell is the function of minerals in the diet. Yolk color of the eggs also did not differ $(\mathrm{P}>0.05)$ significantly among treatments because chicken were not subjected to green feeding that influence yolk color.

In the current study, 47.2, 39.4, 21.41 and 15.3 net Ethiopian Birr from the sale of eggs was obtained per bird from T2, T3, T4 and T1 respectively. The net return did not considered the value of poultry litter that can be used as a bio fertilizer and animal feed. Compared to the other rations higher net return was obtained from using treatment two (T2). Compared to the previous work done using commercial diet by Tesf et al. [17] higher net return was obtained in the current study.

\section{Conclusion}

Locally available protein and energy resource feed can be used for the formulation of nutritionally balanced and economically feasible diet for fayoumi layers chickens. Livestock experts and researchers should have to assist poultry producers who are willing to introduce Fayoumi chickens and while they are formulating diet for them from the available feed resources.

\section{Recommendation}

Locally formulated ration from $0.5 \%$ limestone, $0.5 \%$ salt, $1 \%$ layers premixes, $28 \%$ wheat bran, $3.5 \%$ fish meal, $11.5 \%$ soybean, $32 \%$ maize and $23 \%$ noug cake was found to be nutritionally and financially feasible and recommendable in areas with similar climatic conditions to Adami Tulu area and in area where these feed ingredients are available.

\section{References}

[1] Evan J. (2010). Poultry breed facts. The way of chicken.com /index.php/2017/05/10. https://wordpress.org

[2] Ann. (2017). The way of chicken.com /index.php/2017/05/10. https://wordpress.org

[3] Hunduma Dinka, Regassa, Chala Fufa Dawo, Samson Leta, Endale Bekana. (2010). Socio- economic importance and management of village chicken production in rift valley of Oromia, Ethiopia. Livestock Research for Rural Development 22 (11).

[4] Branckaert, RDS, Guèye E. (2000). FAO's Programme for support to family poultry production. http://www.husdry.kvl.dk/htm/tune99/24.branckaert.thm.

[5] Solomon D. (2004). Egg production performance of local and White Leghorn hens under intensive and rural house hold conditions in Ethiopia. Livestock Research for Rural Development 16 (2) 2004.

[6] ESGPIP (Ethiopian sheep and goat productivity improvement program). (2008). Formulation of rations for sheep and goats. Technical Bulletin No. 16.

[7] Gopalakrishnan CA, Mohanal M G.. (2004). Livestock and poultry Enterprises for rural development.

[8] Richard O, Church D C. (1998). Livestock feeds and feeding. $4^{\text {th }}$ ed. Prentice Hall International (UK) Limited, London.

[9] Adugna T. (2007). Feed Resource for producing Export Quality meat and meat Livestock in Ethiopia. Examples from selected Woredas in Oromia and SNNP Regional states. December, 2007. Addis Ababa, Ethiopia. pp. 46, 52, 75.

[10] Smith J A. (2001). The tropical Agriculturalist. Poultry.

[11] ATARC (Adami Tulu Agricultural Research Center) (2019). Metrological.

[12] SAS. (2001). SAS user`s Guide: statistics, Release 8.2. SAS Inst., carry. Nc.

[13] CIMMT (International Maize and Wheat Improvement Center). (1988). From Agronomic Data to Farmer Recommendations: An economics training manual. CIMMT, DF, Mexico.

[14] Ehui S, Rey B. (1992). Partial budget analysis for on station and on-farm small ruminant Production systems research method and data requirements. In: proceeding of the first Biennial conference of the Africa small ruminant Research net work. ILRAD, Nirobi, Kenya 10-14 December, 1990.

[15] AOAC (Association of official Analytical chemist). (1990). 15th ed. AOAC Arlington, vergina, USA.

[16] Valkonen E, Venäläinen E, Rossow L, Valaja J. (2008). Effects of dietary energy content on the performance of laying hens in furnished and conventional cages. Poult Sci. 2008 May; 87 (5): 844-52. doi: 10.3382/ps.2007-00237. 
[17] Tesfa Geleta, Samson Leta, Endalew Bekana. (2013). Production performance of Fayoumi chickens under intensive management condition of Adami Tuluresearch center. International Journal of Livestock Product. Vol. 4 (10), pp. 172-176, December, 2013.

[18] Khan, M. K. J, Khatun, M. J, Bhiyan, M. S. A, Sharmin R. (2006). Production performance of fayoumi chiken under intensive management. Pakistan Journal of Biological science 9 (2): 179-181, 2006.

[19] Ribeiro PAP, Matos, Jr JB, Lara LJC, Araújo L F, Albuquerque R, Baião NC. (2014). Effect of dietary energy concentration on performance parameters and egg quality of white leghorn laying hens. Brazilian Journal of Poultry
Science. Rev. Bras. Cienc. Avic. vol. 16 no. 4 Campinas Oct./Dec. 2014. http://dx.doi.org/10.1590/1516635X1604381-388

[20] Asghedom, G, Kjos, N. P, Austbo D. (2008). Effect of Fishmeal Supplementation on Egg Production of Rhode Island Red Layers in Eritrea. College of Agriculture and Aquatic Sciences, University of Asmara., In: Tanzania J. Agric. Sc. (2006) Vol. 7 No. 2, 77-86.

[21] Tesfa Geleta, Samson Leta. (2015). Effect of dietary energy and protein combination on egg production performance of Fayoumi chickens. Basic Research Journal of Agricultural Science and Review ISSN 2315-6880 Vol. 4 (3) pp. 089-093 March 2015. 